\title{
Inkonsistensi Putusan MK No. 49/PUU-X/2012 dan Putusan MK No. 22/PUU-XVII/2019 Terkait Peraturan Jabatan Notaris
}

\author{
Yunita Mahendrawati H.P.1
}

${ }^{1}$ Program Studi Magister (S2) Kenotariatan Fakultas Hukum Universitas Udayana, E-mail: yunitamahendrawati@gmail.com

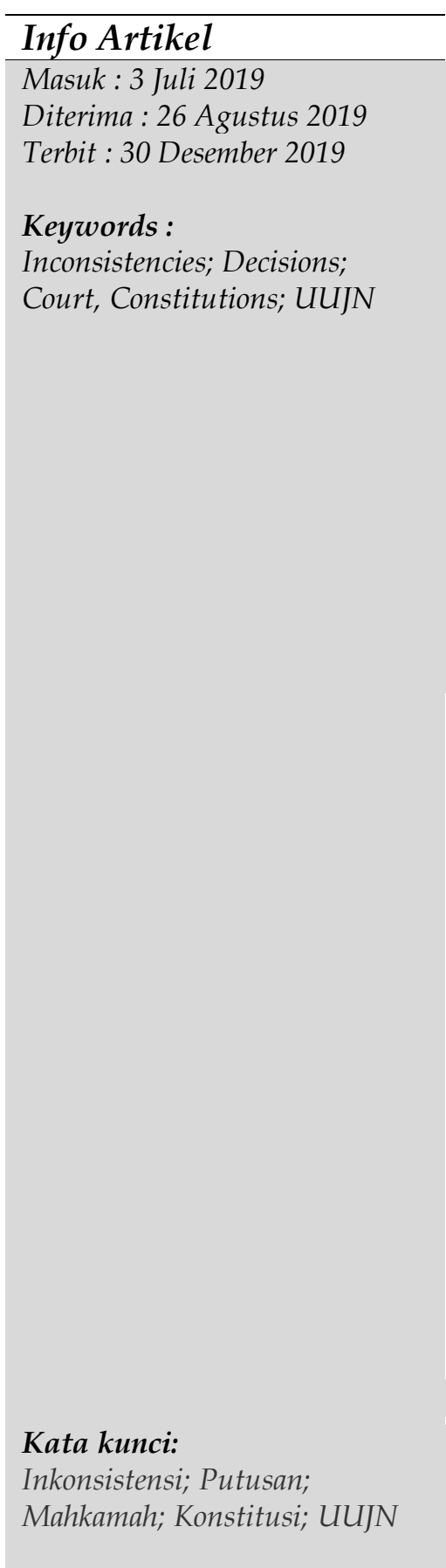

\begin{abstract}
Decision of the Constitutional Court No. 49 / PUU-X / 2012 which cancels the phrase "with the approval of the MPD" resulting in the authority of the MPD stipulated in Article 66 paragraph (1) of Law No. 30 of 2004 concerning the Position of Notary (UUJN) resulting in the loss of MPD's authority to give approval to investigators, prosecutors or judges for judicial proceedings involving notary public. Then the article was the subject of a lawsuit to be petitioned for material testing at the Constitutional Court, which was then terminated in Decision of the Constitutional Court No. 22 / PUU-XVII / 2019. However, the ruling of the Constitutional Court's ruling gave rise to a ruling that was different from the previous ruling, which stated that "Article 66 paragraph (1) UUJNP does not contradict the 1945 Constitution". The purpose of this paper is to find out changes to the regulations of the position of the Notary public after Decision of the Constitutional Court No. 49 / PUU-X / 2012 and to assess the inconsistency of the Constitutional Court's Decision on the review of material in Article 66 UUJN. This research is a normative legal research using the law approach, conceptual approach and case approach. The analyzed legal materials are primary and secondary legal materials with descriptive, comparative, evaluative and argumentative analysis techniques. Amendment to the regulation of the Notary Public after Decision of the Constitutional Court No. 49 / PUU-X / 2012 which abolished the MPD's authority in giving approval, has been replaced by MKN as stipulated in Article 66 paragraph (1) of the UUJNP. Inconsistencies that occur in Decision of the Constitutional Court No. 49 / PUU-X/2012 and Decision of the Constitutional Court No. 22 / PUU-XVII / 2019 in the case of material testing of Article 66, due to differences in the Constitutional Court's considerations which resulted in differences in ruling on the previous Decree declared contrary to the 1945 Constitution whereas the most recent Decision was stated not to contradict the 1945 Constitution. The legal implications of the inconsistency have resulted in legal uncertainty and decreased public confidence in the judiciary.
\end{abstract}

\begin{tabular}{l}
\hline Abstrak \\
\hline Putusan Mahkamah Konstitusi (MK) No. 49/PUU-X/2012 telah \\
membatalkan frasa "dengan persetujuan Majelis Pengawas \\
Daerah" Pada Pasal 66 ayat (1) Undang-Undang No. 30 Tahun \\
2004 tentang Jabatan Notaris (UUJN) mengakibatkan hilangnya
\end{tabular}




\author{
Corresponding Author: \\ Yunita mahendrawati, E-mail: \\ yunitmahendrawati@gmail.com \\ DOI : \\ 10.24843/AC.2019.v04.i03.p10
}

kewenangan MPD yakni terkait pemberian persetujuan terkait proses peradilan oleh penyidik, penuntut umum, atau hakim. Namun dengan lahirnya Undang-Undang Nomor 2 Tahun 2014 tentang Perubahan Atas UUJN (UUJNP) kembali menghadirkan frasa yang pernah dibatalkan oleh putusan MK dengan nama badan yang berbeda yaitu "Majelis Kehormatan Notaris $(M K N)^{\prime \prime}$ di pasal yang sama yang pernah dibatalkan oleh $M K$ yakni Pasal 66 ayat (1). Kemudian pasal tersebut kembali menjadi pokok gugatan perkara untuk dimohonkan pengujian secara materiil di MK yang kemudian diputus dalam Putusan MK No. 22 /PUU-XVII/2019. Namun amar putusan MK ini memunculkan amar yang berbeda dengan putusan sebelumnya, yang menyatakan bahwa "Pasal 66 ayat (1) UUJNP tidak bertentangan dengan UUD 1945". Adapun tujuan dari penulisan ini yakni untuk mengetahui perubahan peraturan jabatan Notaris pasca adanya Putusan MK No. 49/PUU-X/2012 dan untuk mengkaiji mengenai inkonsistensi Putusan MK terhadap pengujian materi pada Pasal 66 UUJN. Penelitian ini merupakan penelitian hukum normatif dengan menggunakan pendekatan undang-undang, pendekatan konseptual dan pendekatan kasus. Bahan hukum yang dianalisa berupa bahan hukum primer dan sekunder dengan teknik analisa deskriptif, komparatif, evaluative dan argumentatif. Perubahan pengaturan Notaris pasca Putusan MK No. 49/PUU-X/2012 yang menghapuskan kewenangan MPD dalam memberi persetujuan, telah digantikan oleh MKN yang tertuang dalam Pasal 66 ayat (1) UUJNP. Inkonsistensi yang terjadi dalam Putusan MK No. 49/PUU-X/2012 dan MK No. 22/PUU-XVII/2019 dalam hal pengujian materiil Pasal 66, disebabkan karena perbedaan pertimbangan $M K$ yang mengakibatkan perbedaan amar pada Putusam sebelumnya dinyatakan bertentangan dengan UUD 1945 sedangkan pada Putusan terbaru dinyatakan tidak bertentangan dengan UUD 1945. Implikasi hukum akibat inkonsistensi tersebut mengakibatkan adanya ketidakpastian hukum dan menurunnya kepercayaan publik kepada peradilan.

\section{Pendahuluan}

Notaris merupakan seseorang yang diberi kewenangan untuk membuat akta yang bersifat otentiK. Keberadaanya sebenarnya sudah ada dari sebelum Indonesia merdeka. Ketentuan peraturan tentang Notaris sendiri sudah mengalami beberapa kali perubahan. Ketentuan pengaturan tersebut mengenai Notaris terdapat dalam "Reglement op Het Notarisin Nederlands Indie (stbl.1860:3)", yang kemudian digantikan menjadi Undang-Undang Nomor 30 Tahun 2004 tentang Jabatan Notaris" (UUJN). Pada tanggal 17 Januari 2014 disahkanlah perubahan atas UUJN yaitu "Undang-Undang Nomor 2 Tahun 2014 tentang Perubahan Atas Undang-Undang Nomor 30 Tahun 2004 tentang Jabatan Notaris (UUJNP). Letak arti penting jabatan Notaris adalah pada produk akta yang dihasilkannya yang diakui keautentikannya oleh undangundang yang didalamnya tertuang suatu perjanjian maupun perbuatan yang dilakukan oleh subyek hukum.

Akta Notaris didalam persidangan dapat menjadi alat bukti yang sah dan juga sempurna khususnya mengenai perkara yang berkaitan dengan isi akta tersebut, selama masih terjaga keautentikannya. Akta sebagai alat bukti surat memegang peranan sangat penting dalam suatu 
proses pembuktian, maka dari itu Notaris juga memiliki peranan sebagai legal advice yang harus mampu melakukan verifikasi serta memastikan kesesuaian akta terhadap aturan perundangundangan dengan memperhatikan apakah unsur-unsur untuk perjanjian dianggap sah sudah terpenuhi atau belum sebelum dituangkan ke dalam isi akta. Akta Notaris memiliki kekuatan pembuktian yang sempurna dan juga mengikat untuk para pihak yang mengikatkan dirinya dengan akta itu. Pembuktian sempurna berarti akta tersebut saja sudah dapat membuktikan adanya peristiwa hukum walaupun tidak dilengkapi bukti-bukti yang lain. Mengikat berarti isi dari akta dianggap benar serta itulah yang terjadi. ${ }^{1}$

Pentingnya peranan Notaris dalam membuat akta otentik tentunya seringkali memposisikan Notaris sebagai saksi atau bahkan tersangka didalam suatu perkara hukum baik itu perdata atau pidana. ${ }^{2}$ Mengenai proses peradilan yang melibatkan Notaris maupun produknya ditentukan pengaturannya dalam UUJN. Adapun Pasal 66 ayat (1) UUJN menentukan bahwa "untuk kepentingan proses peradilan, penyidik, penuntut umum, atau hakim dengan persetujuan Majelis Pengawas Daerah berwenang mengambil fotokopi Minuta Akta dan/atau surat-surat yang dilekatkan pada Minuta Akta atau Protokol Notaris dalam penyimpanan Notaris, dan memanggil Notaris untuk hadir dalam pemeriksaan yang berkaitan dengan akta yang dibuatnya atau Protokol Notaris yang berada dalam penyimpanannya". Aturan tersebut rupanya menimbulkan suatu perkara hukum yang kemudian digugat kepada Mahkamah Konstitusi Republik Indonesia (MK RI) karena dianggap bertentangan dengan Undang-Undang Dasar Negara Republik Indonesia Tahun 1945 (UUD 1945) serta melanggar hak konstitusional maka dilakukanlah pengujian materiil yang pada amar putusannya mengakibatkan Pasal 66 ayat (1) UUJN menjadi tidak berlaku. Putusan MK RI bersifat final dan mengikat (final and binding). ${ }^{3}$ Sehingga berdasarkan putusan itu para aparat penegak hukum khususnya penyidik yang sedang menangani perkara yang melibatkan Notaris, untuk melakukan pemanggilan Notaris guna diperiksa ataupun akan mengambil produk dari Notaris tidak memerlukan lagi persetujuan dari Majelis Pengawas Daerah (MPD).

Putusan MK yang final dan mengikat seharusnya putusan tersebut tidak dapat dirubah melalui upaya hukum apapun yang berarti bahwa putusan tersebut menjadi putusan yang pertama dan terakhir kalinya untuk pokok perkara yang sama. Namun frasa "dengan sepersetujuan" yang pernah dibatalkan oleh Putusan MK No. 49/PUU-X/2012 kembali dituangkan dalam UUJNP pada Pasal 66 ayat (1) dengan nama badan yang berbeda yakni MKN sehingga menyebabkan gugatan kembali ke MK untuk dimohonkan dilakukan pengujian secara materiil terhadap pasal tersebut karena dianggap telah melanggar hak konstitusional seseorang serta bertentangan dengan UUD 1945. Namun sayangnya, amar putusan terhadap permohonan akan pengujian materiil Pasal 66 ayat (1) UUJNP tersebut yang tertuang dalam Putusan MK No. 22/PUUXVII/2019 ditolak seluruhnya oleh majelis hakim karena dianggap pasal yang menjadi pokok perkara tersebut tidak bertentangan dengan UUD 1945 serta tidak melanggar hak konstitusional warga negara. Terjadinya suatu inkonsistensi terhadap Putusan MK RI mengenai peraturan jabatan Notaris khususnya mengenai muatan materi yang sama dalam pasal yang sama pula pada UUJN maupun UUJNP namun menghasilkan 2 (dua) amar putusan yang berbeda. Ditinjau dari sifat putusan MK seharusnya keberlakuan terhadap putusan itu sejatinya permanen atau tetap dan berlaku mengikat. Namun bilamana substansi yang sama dihadirkan kembali dalam suatu undang-undang yang dibentuk pasca putusan MK tersebut, tentunya cenderung bertentangan dengan sifat dari putusan MK RI itu sendiri karena dapat dikatakan terjadi suatu upaya hukum untuk kembali menghadirkan frasa yang dibatalkan oleh putusan MK. Namun ketika materi Pasal yang sama kembali dimohonkan untuk dilakukan pengujian

${ }^{1}$ Arliman, L., (2015), Notaris Dan Penegakan Hukum Oleh Hakim, Yogyakarta: CV Budi Utama, h. 4.

2 Mulyoto, (2010), Kesalahan Notaris Dalam Pembuatan Akta Perubahan Dasar CV, Yogyakarta: Cakrawala Media, h. 2.

${ }^{3}$ Siahaan, M., (2011), Hukum Acara Mahkamah Konstitusi Republik Indonesia, Edisi 2 Cetakan 1, Jakarta: Sinar Grafika, h. 202. 
materiil ke MK RI ternyata dalam amar putusannya malah tidak konsisten dengan putusan MK terdahulu. Untuk itu penelitian dengan judul "Inkonsistensi Putusan Mahkamah Konstitusi Terkait Peraturan Jabatan Notaris (Analisis Putusan MK No. 49/PUU-X/2012 dan Putusan MK No. 22/PUU-XVII/2019)" akan mengkaji dan membahas 2 (dua) rumusan permasalahan, yakni: "Bagaimanakah pengaturan peraturan jabatan Notaris pasca putusan Mk No. 49/PUUX/2012? Serta Bagaimanakah implikasi hukum atas inkonsistensi yang terjadi pada Putusan MK No 49/PUU-X/2012 dengan Putusan MK No. 22/PUU-XVII/2019 terhadap Pasal 66 UUJNP?."

Penulisan Jurnal ini mempunyai 2 (dua) macam tujuan. Adapun tujuan umumnya yakni guna mengembangkan bidang keilmuan hukum khususnya mengenai pengaturan jabatan notaris dalam kaitannya terhadap adanya Putusan MK mengenai pengujian terhadap UUJN. Sedangkan tujuan khususnya yakni untuk mengetahui terkait perubahan pengaturan jabatan Notaris pasca adanya "Putusan MK No. 49/PUU-X/2012" serta untuk mengkaji mengenai implikasi hukum atas inkonsistensi yang terjadi dalam putusan MK mengenai materi muatan Pasal 66 UUJNP. Kajian teoritis yang berhubungan dengan penelitian ini diharapkan bisa dijadikan referensi terkait proses penegakan hukum yang melibatkan Notaris, serta menjadi tambahan pemikiran terhadap penyempurnaan peraturan perundang-undang yang mengatur terkait proses penegakan hukum yang melibatkan Notaris agar sesuai dengan UUD 1945.

Manfaat penelitian ini secara khusus ditujukan kepada Notaris, aparat penegak hukum, MK RI, akademisi, serta masyarakat luas yang berkepentingan. Untuk Notaris, diharapkan bisa memberikan pertimbangan untuk selalu mentaati peraturan serta Kode Etik Notaris yang berlaku dalam mengemban tugasnya melayani masyarakat dan negara. Bagi MK RI diharapkan dapat memberikan masukan sebelum memutus suatu permohonan pengujian undang-undang agar tetap mempertimbangkan Putusan MK sebelumnya serta tetap berdasarkan pada UUD 1945. Bagi akademisi diharapkan dapat berfungsi untuk bahan pemikiran serta penunjang dalam kegiatan perkuliahan dalam hal Proses peradilan yang melibatkan Notaris bila ditinjau dari UUJNP serta Putusan MK No. 49/PUU-X/2012. Penelitian ini diharapkan pula dapat menjadi petunjuk bagi masyarakat ketika mengalami suatu perkara hukum yang melibatkan Notaris serta produknya dalam proses peradilan.

\section{Metode Penelitian}

Penelitian ini merupakan sebuah penelitian hukum normatif yang akan mengkaji aturan hukum yang diberlakukan sebagai sebuah norma dalam warga negara. Penelitian hukum normatif yang meneliti serta menelaah bahan pustaka, disebut juga "penelitian hukum kepustakaan, penelitian hukum teoritis/dogmatis". ${ }^{4}$ Penelitian dilakukan dengan melakukan suatu proses dimana dilakukan pencarian aturan, prinsip, serta doktrin hukum yang nantinya akan digunakan memecahkan permasalahan yang menjadi isu hukum yang sedang diteliti. ${ }^{5}$ Legal issue dari penelitian ini adalah adanya konflik norma antara Putusan MK No. 49/PUUX/2012 dengan Putusan MK No. 22/PUU-XVII/2019. Adapun pendekatan yang digunakan dalam penelitian ini meliputi pendekatan perundang-undangan, pendekatan konseptual serta pendekatan kasus. Pendekatan perundang-undangan yakni dengan menelaah serta mengkaji suatu undang-undang serta peraturan yang berkaitan dengan rumusan permasalahan yang akan dibahas. Pendekatan undang-undang dapat membantu dalam menganalisa terkait konsisten tidaknya suatu ketentuan perundang-undangan dengan ketentuan perundangundangan lainnya khususnya sesuai dengan UUD 1945. Pendekatan konseptual penulis mengacu pada prinsip hukum yang dijadikan pijakan dalam membangun argumentasi hukum. Sedangkan pendekatan kasus ditekankan pada "ratio decidendi", yaitu mengenai alasan atau

\footnotetext{
${ }^{4}$ Ishaq, (2017), Metode Penelitian Hukum, Bandung: Alfabeta, h. 66

${ }^{5}$ Marzuki, P.M (2005), Penelitian Hukum, Jakarta: Prenada Media, h. 35.
} 
dasar hukum dari suatu keputusan yang dibuat oleh hakim. ${ }^{6}$ Bahan hukum pada penelitian ini menggunakan Bahan hukum primer dan sekunder. Bahan hukum adalah bahan hukum berupa pernyataan tertulis yang ditetapkan atau dibuat oleh pemerintah yang meliputi undangundang, putusan putusan, serta peraturan-peraturan eksekutif maupun administratif. ${ }^{7}$ Penelitian ini bahan hukum primernya adalah UUD 1945, UUJN, UUJNP, Putusan MK No. 49/PUU-X/2012, Putusan MK No. 22 /PUU-XVII/2019, Undang-Undang Nomor 24 Tahun 2003 tentang Mahkamah Konstitusi (UUMK) dan Undang-Undang Nomor 8 Tahun 2011 tentang Perubahan Atas Undang-Undang Nomor 24 Tahun 2003 tentang Mahkamah Konstitusi (UUMKP). Sedangkan bahan hukum sekunder adalah bahan hukum yang dikategorikan sebagai hasil penelitian seperti jurnal, buku, serta karya ilmiah lainnya yang bersumber pada keilmuan dalam bidang hukum yang dapat menunjang penelitian ini. Teknik untuk mengumpulkan bahan hukum yang digunakan berupa studi dokumen yakni dengan mempelajari bahan kepustakaan yang berkaitan dengan rumusan masalah. Kemudian setelah bahan-bahan terkumpul dilanjutkan dengan proses analisa untuk memperoleh jawaban atas rumusan masalah berupa argumentasi-argumentasi hukum. Teknik analisis yang digunakan yakni teknik deskriptif yaitu dengan memaparkan suatu peristiwa hukum yang terjadi, kemudian dengan teknik komparatif yaitu membandingkan antara pendapat atau alasan hukum yang satu dengan lain dalam hal ini putusan MK yang terdahulu dengan yang setelahnya, lalu dilanjutkan dengan teknik evaluatif dengan melakukan evaluasi terhadap suatu kondisi hukum, serta teknik argumentatif yang digunakan terakhir untuk memperoleh argumentasi dalam menjawab permasalahan hingga sampai pada kesimpulan peneliti.

\section{Hasil dan Pembahasan}

\subsection{Pengaturan Peraturan Jabatan Notaris Pasca Putusan MK No. 49/PUU- $\mathrm{X} / 2012$}

\subsubsection{Analisa sifat Putusan Mahkamah Konstitusi No. 49/PUU-X/2012}

MK RI sebagai lembaga kehakiman memiliki peranan penting untuk menegakkan konstitusi dalam sebuah negara berdasarkan amanat dari UUD 1945. Kewenangan MK RI dalam melakukan pengujian terhadap sebuah undang-undang dengan UUD RI 1945, memutus sengketa terhadap kewenangan sebuah lembaga negara, memutus pembubaran partai politik serta untuk memutuskan terhadap perselisihan hasil pemilu merupakan kewenangan yang diamanatkan oleh UUD 1945 Pasal 24C yang putusannya final serta mengikat ${ }^{8}$, yang kemudian diatur lebih lanjut dalam “Undang-Undang No. 24 Tahun 2003 Tentang Mahkamah Konstitusi" (UUMK). Kewenangan MK RI untuk melakukan pengujian undang-undang terhadap UUD 1945 merupakan sebuah kewenangan yang penting guna menjamin bahwa lembaga eksekutif serta legislatif untuk menciptakan suatu peraturan maupun dalam melaksanakan peraturan tersebut tetap berpedoman terhadap konstitusi sebagai hukum tertinggi. Pengujian atau judicial review terhadap suatu ketentuan perundang-undangan perlu untuk dilakukan penilaian terhadap suatu peraturan yang lebih tinggi bila ditinjau secara hirarki. ${ }^{9}$ Pasal 24C UUD 1945 memberikan kewenangan kepada Mahkamah Konstitusi untuk melakukan pengujian suatu

\footnotetext{
${ }^{6}$ Ranuhandoko, (2013), Terminologi Hukum, Jakarta: Sinar Grafika, h. 419

${ }^{7}$ Ibid, h. 419.

${ }^{8}$ Indrayana, D., \& Mochtar, Z. A. (2007). Komparasi Sifat Mengikat Putusan Judicial Review Mahkamah Konstitusi dan Pengadilan Tata Usaha Negara. Mimbar Hukum-Fakultas Hukum Universitas Gadjah Mada, 19(3), 437-454 h. 437.

9 Huda, N. \& Nazriyah, R., (2011), Teori dan Pengujian Peraturan Perundang-undangan, Bandung: Nusamedia, h. 131.
} 
undang-undang terhadap UUD $1945 .{ }^{10}$ Putusan MK merupakan jenis putusan akhir, artinya bahwa setiap putusan final dan mengikat sebagaimana dapat dilihat dalam ketentuan hukum acara Mahkamah Konstitusi. Memang pada perkara sengketa kewenangan antar lembaga negara yang kewenangannya diberikan oleh UUD 1945, MK RI mengenal putusan sementara (sela) agar tidak terjadi kekacauan (chaos) akibat dari tidak terlayaninya kepentingan umum oleh lembaga-lembaga yang bersangkutan, namun pada pengujian undang-undang hanya dikenal putusan akhir. ${ }^{11}$ Putusan MK memperoleh kekuatan hukum tetap sejak diucapkan dalam sidang pleno yang terbuka untuk umum. ${ }^{12}$ Putusan MK RI dilihat dari amar putusannya memiliki sifat declaratoir constitutive. Declaratoir artinya putusan tersebut hanya menyakatan hukum yang ada tetapi hakim tidak melakukan penghukuman, sedangkan bersifat constitutive artinya putusan tersebut menciptakan suatu aturan atau keadaan hukum yang baru. ${ }^{13}$ Suatu keputusan yang dibuat oleh MK RI harus dimuat dalam Berita Negara dengan tenggang waktu maksimal 30 (tiga puluh hari) sejak putusan terucap. ${ }^{14}$

MK RI yang memiliki kewenangan dalam menguji undang-undang berfungsi melindungi konstitusi agar menjamin hak asasi manusia (HAM) serta susunan ketatanegaraan dan pembagian kekuasaan secara fundamental. ${ }^{15}$ Ada 2 (dua) macam hak untuk pengujian terhadap undang-undang yaitu hak menguji secara formal dan secara materiil. ${ }^{16}$ Peraturan perundangundangan yang akan direvisi atau disusun setidaknya harus memiliki landasan yuridis, filosofis dan juga sosiologis. Secara yuridis terdapat landasan yuridis formal dan material. Landasan yuridis formal yakni dasar dari kewenangan pembuatan peraturan perundangundangan, sedangkan landasan yuridis material yakni dasar dari keberadaan jenis peraturan perundang-undangan yang substansi atau isinya harus sesuai dengan wadahnya serta tidak boleh bertentangan dengan substansi peraturan perundang-undangan yang lebih tinggi serta kepentingan umum. ${ }^{17}$ Artinya bilamana suatu undang-undang secara substansi dianggap bertentangan terhadap Putusan MK maupun UUD 1945, maka peraturan tersebut dapat digugat atau dibatalkan.

Amar "Putusan MK No. 49/PUU-X/2012" yang mengabulkan permohonan pemohon telah membatalkan frasa "dengan persetujuan Majelis Pengawas Daerah" bermula dari permohonan yang diajukan oleh Kant Kamal melaui kuasa hukumnya untuk melakukan uji materiil terhadap UUJN, dengan menggunakan dalil bahwa "Pasal 66 ayat (1) UUJN bertentangan dengan UUD 1945 yakni Pasal 27 ayat (1) dan Pasal 28D ayat (1)". Pasal-pasal tersebut mengandung prinsip kesamaan dimuka hukum atau mengandung prinsip "Equality before the law". Prinsip tersebut dimaksudkan agar Notaris yang merupakan warga negara agar diberlakukan sama dalam menjalani proses penegakan hukum tanpa pengecualian. ${ }^{18}$ Dalam permohonan tersebut, pemohon menyatakan bahwa hak konstitusionalnya dilanggar dengan

10 Nafiatul, M., \& Maryam, N.H. (2015). Munawaroh, N., \& Hidayati, M. N. (2015). Integrasi Pengujian Peraturan Perundang-Undangan di Mahkamah Konstitusi sebagai Upaya Pembangunan Hukum Indonesia. Jurnal Hukum Ius Quia Iustum, 22(2), 255-268, h.256.

${ }^{11}$ Indrayana, D., \& Mochtar, Z. A., (2007), Op. Cit., h.439

12 Soeroso, F. L. (2014). Aspek keadilan dalam sifat final putusan Mahkamah Konstitusi. Jurnal Konstitusi, 11(1), 64-84, h. 65

${ }^{13}$ Indrayana, D., \& Mochtar, Z. A. (2007), Op.Cit, h.439

14 Amrizal, J.P., (2011),Implikasi Hukum Putusan Mahkamah Konstitusi, Kanun Jurnal Hukum, 12(53), 77-94, h. 85

${ }^{15}$ Munawaroh, N., \& Hidayati, M. N. (2015). Integrasi Pengujian Peraturan PerundangUndangan di Mahkamah Konstitusi sebagai Upaya Pembangunan Hukum Indonesia. Jurnal Hukum Ius Quia Iustum, 22(2), 255-268, h.259

${ }^{16}$ Amrizal, J.P. (2011). Op. Cit., h. 84

17 Ranggawidjaja, R., (1998), Pengantar Ilmu Perundang-undangan Indonesia, Bandung: Mandar Maju, h. 44-45

${ }^{18}$ Kurnianingrum, T. P. (2016). Dampak Hukum Putusan MK No. 49/PUU-X/2012 Terhadap Perlindungan Hukum Bagi Notaris. Kajian, 18(3), 189-201, h. 197 
berlakunya frasa "dengan persetujuan Majelis Pengawas Daerah" dalam Pasal 66 ayat (1) UUJN, yang berbunyi "untuk kepentingan proses peradilan, penyidik, penuntut umum, atau hakim dengan persetujuan Majelis Pengawas Daerah berwenang:

a. Mengambil fotokopi Minuta Akta dan/atau surat-surat yang dilekatkan pada Minuta Akta atau Protokol Notaris dalam penyimpanan Notaris dan;

b. Memanggil Notaris untuk hadir dalam pemeriksaan yang berkaitan dengan akta yang dibuatnya atau Protokol Notaris yang berada dalam penyimpanan Notaris."

Pelanggaran terhadap hak konstitusional pemohon dirasakan karena berlakunya aturan tersebut menyebabkan proses penyidikan yang sedang dilakukan oleh Polisi Daerah (Polda) Metro Jaya terkait laporan polisi yang dibuat oleh pemohon menjadi dihentikan sehingga menghambat pemeriksaan terhadap Notaris yang bersangkutan. Adapun kronologinya dimana laporan polisi sebagai tanda bukti lapor yang dibuat oleh pemohon mengalami kendala yang disebabkan oleh tidak diperolehnya persetujuan dari MPD krpada Penyidik Kepolisian untuk melakukan pemeriksaan kepada Notaris sebagai saksi untuk dimintai keterangannya terkait dugaan tindak pidana yang melibatkan Syane Runtulalo, S.H, Notaris di Cianjur. Oleh karena tidak mendapatkan persetujuan dari MPD untuk melakukan pemeriksaan kepada Notaris bersangkutan untuk didengar kesaksiannya selaku yang membuat akta, Penyidik Polda Metro Jaya dalam menjalani proses penyidikan mengalami kendala dalam mengungkap pelaku tindak pidana tersebut sehingga berakhir pada terbitnya "Surat Perintah Penghentian Penyidikan" (SP3). Oleh karena itu pemohon merasa bahwa ketentuan Pasal 66 ayat (1) UUJN bertentangan dengan Pasal 27 ayat (1) dan Pasal 28D ayat (1) UUD 1945. Frasa yang dimohonkan diuji secara materiil dalam pasal tersebut dapat dijadikan modus oleh pelaku-pelaku kejahatan untuk bersembunyi atau berlindung dibalik pasal tersebut. Persetujuan MPD untuk memanggil Notaris ataupun mengambil produk Notaris akan membutuhkan waktu yang cukup lama serta sulit untuk dapat diperiksa penyidik kepolisian dan tidak menutup kemungkinan pelakunya tidak dapat terungkap, dan berakibat lumpuh atau hilangnya hak konstitusional serta hak asasi bagi para pencari keadilan. Berdasarkan fakta hukum dan pertimbangannya Majelis Hakim MK RI menyimpulkan bahwa permohonan yang diajukan beralasan menurut hukum dan frasa "dengan persetujuan MPD" dianggap bertentangan dengan UUD 1945. Yang menjadi pertimbangan oleh Hakim MK sehingga mengabulkan permohonan pemohon diantaranya bahwa sebagaimana dalil terkait Pasal 66 ayat (1) UUJN menimbulkan kendala bagi Kepolisian dalam melakukan proses penyidikan karena harus terlebih dahulu meminta izin kepada MPD dianggap bertentangan dengan UUD 1945. Kemudian pertimbangan hakim terkait "proses peradilan yang dilakukan oleh penyidik, penuntut umum dan hakim yang hanya dapat dilakukan setelah ada persetujuan dari MPD bertentangan dengan prinsip equal protection". Selain itu frase "Persetujuan MPD" dianggap bertentangan juga dengan prinsip independensi dalam proses peradilan. Oleh karena berbagai pertimbangan itulah Hakim MK RI memutuskan dalam amar putusannya mengabulkan seluruhnya permohonan pemohon serta membatalkan frasa "dengan persetujuan MPD" sehingga tidak berlaku lagi. Permasalahan hukum yang diacarakan melalui MK RI, putusannya memberikan suatu jaminan kepada para pihaknya karena konstitusi merupakan derajat hukum tertinggi. ${ }^{19}$ Sehingga sejak putusan tersebut dibacakan, maka secara otomatis Pasal 66 ayat (1) tersebut telah dicabut dan tidak mengikat, mengingat sifat final and binding pada Putusan MK.

\subsubsection{Perubahan Peraturan Jabatan Notaris Pasca Putusan MK No. 49/PUU- $\mathrm{X} / 2012$}

Pembentukan maupun perubahan atas suatu aturan perundang-undangan merupakan wujud dari politik hukum di Indonesia. Politik hukum dilakukan dalam menyempurnakan suatu regulasi yang sudah ada dengan pergantian maupun pembentukan regulasi hukum yang baru

${ }^{19}$ Soeroso, F. L. (2014). Aspek keadilan dalam sifat final putusan Mahkamah Konstitusi. Jurnal Konstitusi, 11(1), 64-84, h. 81 
untuk mencapai cita-cita atau tujuan dari hukum itu sendiri. Sehingga dapat dikatakan bahwa politik hukum akan memilh hukum-hukum mana saja yang diberlakukan, yang tidak berlaku lagi guna tercapainya tujuan dari hukum sebagaimana diamanatkan dalam UUD 1945. Jabatan Notaris di Indonesia awal mulanya diatur dalam "Reglement op Het Notarisin Nederlands Indie (stbl.1860:3)". Kemudian pada tanggal 6 Oktober 2004 di Jakarta, diundangkanlah UUJN yang didalamnya termuat 92 pasal yang terbagi menjadi 12 Bab. Selama Sembilan tahun UUJN menjadi dasar hukum dalam pelaksanaan Jabatan Notaris sebelum diundangkannya UUJNP, UUJN telah mengalami dua kali pengujian terhadap UUD 1945 di Mahkamah Konstitusi. ${ }^{20}$ Perkara pertama yaitu No. 009-014/PUU-III/2005 tentang permohonan pengujian formal dan juga material terhadap UUJN yang diajukan oleh organisasi Notaris yang tergabung dalam Persatuan Notaris Reformasi Indonesia (PERNORI) serta Himpunan Notaris Indonesia (HNI), namun amar putusan pada perkara tersebut menyatakan bahwa permohonan para pemohon ditolak dengan pertimbangan bahwa permohonan tersebut tidak cukup beralasan. Berbeda halnya dengan putusan perkara kedua yakni perkara No. 43/PUU-X/2012 yang diajukan oleh Kant Kamal melalui kuasa hukumnya untuk dimohonkan pengujian materiil terhadap Pasal 66 ayat (1) UUJN dengan amar putusan mengabulkan keseluruhan permohonan pemohon. Pasal 66 ayat (1) UUJN yang menentukan bahwa untuk penyidik, penuntut umum dan hakim agar dapat memanggil Notaris atau mengambil fotokopi produk Notaris dalam hal ini Minuta Akta serta Protokol Notaris terlebih dahulu harus mendapatkan persetujuan dari MPD dinyatakan bertentangan dengan UUD 1945. Frasa "Dengan persetujuan Majelis Pengawas Daerah" yang menjadi pokok permohonan pemohon dianggap merugikan hak konstitusional dalam memperoleh hak untuk memilliki kedudukan yang sama dimuka hukum dan juga memperoleh kepastian hukum. Dengan dikabulkannya keseluruhan permohonan pemohon oleh MK RI maka sejak dibatalkannya frasa tersebut, maka aparat penegak hukum yang akan memanggil Notaris guna diperiksa serta melakukan pengambilan terhadap produk Notaris tidak perlu lagi izin dari MPD.

Putusan MK yang menghapuskan frasa "Dengan Persetujuan MPD" bukanlah menghapuskan aspek perlindungan bagi Notaris, karena Notaris dalam menjalankan sumpahnya untuk menjaga kerahasiaan akta mempunyai Hak dan Kewajiban Ingkar. Namun terkait kewenangan yang dimiliki oleh MPD terjadi perubahan pasca putusan MK tersebut kini hanya terbatas pada Pasal 70 UUJN. Pasca Putusan tersebut Pengurus Pusat Ikatan Notaris Indonesia (PP INI) terus melakukan upaya dalam mempertahankan kewajiban dan hak Notaris untuk menjaga kerahasiaan isi akta dengan melakukan penandatanganan MoU (Memorandum of Understanding) dengan pihak Kepolisian Negara Republik Indonesia (POLRI) berkaitan dengan tatacara pemanggilan Notaris. Bahkan PP INI juga melakukan upaya dengan memberikan masukan kepada para stake holder lainnya seperti kemenkumham hingga tim perumus RUUJN dengan pembentukan Majelis Kehormatan Notaris (MKN) dalam rangka mengatur mekanisme pemeriksaan Notaris berkaitan dengan akta otentik yang dibuatnya. ${ }^{21}$ Kemudian dengan diundangkan dan disahkanlah UUJNP sebagai Undang Undang pembaharuan atas Jabatan Notaris. Dalam UUJNP terdapat perubahan atas UUJN, yang didalamnya terdapat 44 ketentuan pasal yang diubah, terutama mengenai imunitas hukum bagi Notaris maupun produknya yang akan dilibatkan dalam proses peradilan. Adapun imunitas yang dimaksud tersebut adalah dengan kembali dituangkannya frasa "dengan persetujuan" pada pasal yang sama pula dalam UUJNP. Dengan hadirnya suatu badan yang baru yakni MKN yang tercantum dalam bunyi Pasal 66 ayat (1) UUJNP, menyatakan bahwa "untuk kepentingan proses peradilan, penyidik, penuntut umum atau hakim dengan persetujuan MKN berwenang:

${ }^{20}$ Padang, L. A. S. S., (2018), Politik Hukum Kenotariatan Pasca Perubahan Undang-Undang Jabatan Notaris Dalam Menjalankan Jabatannya, Dialogia Iuridica: Jurnal Hukum Bisnis dan Investasi, 9(2),111-126, h. 119-120

${ }^{21}$ Syafran Sofian, (2014), PP INI Lakukan Sosialisasi Menyeluruh-Empat Pasal Krusial UUJN Perubahan Harus Dipahami, Majalah Renvoi, h.27 
a. Mengambil fotokopi Minuta Akta dan/atau surat-surat yang dilekatkan pada Minuta Akta atau Protokol Notaris dalam penyimpanan Notaris; dan

b. Memanggil Notaris untuk hadir dalam pemeriksaan yang berkaitan dengan Akta atau Protokol Notaris yang berada dalam penyimpanan Notaris".

Ketentuan lebih lanjut mengenai MKN, baik itu mengenai tugas dan fungsinya, tata kerta dan anggarannya, syarat tata cara pengangkatan maupun pemberhentiannya, serta struktur organisasinya telah ditentukan dalam Permenkumham Nomor 7 Tahun 2016 tentang Majelis Kehormatan Notaris.

Frasa yang sebelumnya pernah dibatalkan oleh Putusan MK kini hadir kembali dalam UUJNP dengan nama badan yang berbeda yaitu MKN mengakibatkan aparat penegak hukum dalam melakukan proses peradilan yang melibatkan Notaris maupun produknya kembali harus mendapat persetujuan terlebih dahulu dari MKN. Sehingga dapat dikatakan terjadinya inkonsistensi aturan hukum mengenai pemanggilan Notaris maupun pengambilan produk Notaris oleh aparat penegak hukum meskipun telah melalui putusan MK. UUJNP khususnya Pasal 66 ayat (1) secara substansi kewenangan dalam hal "dengan persetujuan" sebenarnya memiliki kontradiksi terhadap Putusan MK yang telah membatalkan frasa pasal tersebut karena dianggap bertentangan dengan UUD 1945. Karena frasa yang dihidupkan kembali tersebut mengakibatkan suatu keharusan bagi aparat hukum untuk memperoleh izin kembali dari MKN untuk menegakan hukum terkait penanganan perkara yang melibatkan Notaris maupun Produknya yang beresiko menghambat proses penegakan hukum bilamana MKN dalam hal ini tidak memberikan persetujuan.

\subsection{Implikasi Hukum Inkonsistensi Putusan MK No. 49/PUU-X/2012 dan Putusan MK No. 22/PUU-XVII/2019}

\subsubsection{Pasal 66 UUJNP sebagai Dasar Gugatan Putusan MK No. 22/PUU- XVII/2019}

Sejak UUJNP diundangkan dan disahkan pada tanggal 15 Januari 2014, terbentuk suatu badan baru yang disebut MKN yang memiliki kewenangan serta kedudukan yang ditentukan dalam Pasal 66 ayat (1) UUJNP mengenai proses peradilan yang melibatkan Notaris maupun produknya harus mendapat persetujuan dari MKN sehingga prosedur pemanggilan Notaris maupun pengambilan fotokopi Minuta Akta Notaris serta protokol yang berada dalam penyimpanannya oleh Penyidik, Penuntut Umum serta Hakim bertambah panjang karena harus kembali mengajukan permohonan tersebut terlebih dahulu kepada MKN. Selain tahapan prosedur yang bertambah, waktu yang dibutuhkan oleh aparat penegak hukum juga bertambah karena MKN memiliki waktu selama maksimal 30 (tiga puluh) hari untuk memberikan jawaban persetujuan atau penolakan, sehingga dapat dikatakan selama maksimal 30 (tiga puluh) hari juga proses penegakan hukum sudah terhambat. Belum lagi bila MKN tidak memberikan persetujuannya untuk melakukan pemanggilan Notaris maupun pengambilan produk Notaris, tentunya akan sangat berdampak terhadap perkara hukum bilamana perkara tersebut sangat berkaitan dengan Notaris serta Produk Notaris dalam mengungkap kebenarannya. Jika ditinjau bunyi dalam Pasal 66 ayat (1) UUJNP, maka kewenangan MKN dalam memberikan persetujuan merupakan kewenangan yang sama seperti yang dimiliki oleh MPD pada Pasal 66 ayat (1) UUJN. ${ }^{22}$ Padahal frasa pada pasal tersebut telah dibatalkan oleh putusan MK karena dianggap telah bertentangan dengan UUD 1945, serta melanggar hak konstitusional dalam hal kesamaan kedudukan dimuka hukum dan kepastian hukum. Namun dengan diundangkannya UUJNP seolah menghidupkan kembali kewenangan MPD yang telah dicabut oleh MK RI meskipun dengan badan yang berbeda yaitu MKN.

${ }^{22}$ Hermawan, U., \& Chalim, M. A. (2017). Kewenangan Majelis Kehormatan Notaris Wilayah Dalam Memberikan Persetujuan Terhadap Pemanggilan Notaris Oleh Penegak Hukum. Jurnal Akta, 4(3), 449-454, h. 450 
Hak konstitusional yang terkandung dalam UUD 1945 merupakan bagian dari konstitusi sehingga negara wajib untuk mewujudkan perlindungan terhadap hak konstitusional tersebut. Fungsi dari keberadaannya adalah untuk membatasi kekuasaan pemerintah dan melindungi hak-hak dasar warga negaranya. ${ }^{23}$ Mengingat pertimbangan Mahkamah Konstitusi atas Pengujian materiil terhadap "Pasal 66 ayat (1) UUJN" yang dalam amar putusannya membatalkan frasa "dengan persetujuan MPD", bahwa memang frasa pada pasal tersebut melanggar hak konstitusional warga dalam konteks persamaan dihadapan hukum, karena bilamana seorang Notaris terlibat kasus hukum harus mendapatkan persetujuan dari MPD terlebih dahulu untuk dapat diperiksa dan diambil fotokopi minuta akta atau protokol notarisnya. Sehingga bila MPD tidak memberikan izin, maka proses penegakan hukum dapat menjadi terhambat, dan tidak menutup kemungkinan bahwa suatu dugaan tindak pidana dapat tidak terungkap kebenarannya. Dengan berlakunya UUJNP yang kembali menghidupkan frasa tersebut tentunya bertentangan dengan putusan MK walaupun badan MPD telah digantikan dengan MKN, namun bunyi dari Pasal 66 ayat (1) UUJNP masih mengandung kewenangan yang sama seperti dalam Pasal 66 ayat (1) UUJN yang telah dibatalkan oleh MK RI, mengingat yang dibatalkan oleh putusan tersebut tidak hanya bagian MPD nya tetapi kesatuan frasa "dengan persetujuan MPD". Karena dengan adanya frasa "dengan persetujuan", dapat berpotensi menghambat proses penegakan hukum bila tidak memperoleh persetujuan. sehingga dengan dalih tujuan dari dibentuknya MKN sebagai lembaga perlindungan hukum bagi Notaris dalam menjalankan tugas dan jabatannya, ${ }^{24}$ dapat kembali berpotensi menimbulkan adanya pelanggaran terhadap hak konstitusional seseorang.

Pertentangan yang terjadi antara putusan MK No. 49/PUU-X/2012 dengan Pasal 66 ayat (1) UUJNP merupakan salah satu dasar diajukannya gugatan ke MK RI untuk kembali dilakukan pengujian materiil terhadap UUJN karena dianggap melanggar hak konstitusional seseorang. Adapun gugatan perkara MK No. 22/PUU-XVII/2019 diajukan oleh Guntoro yang merupakan korban tindak pidana atas pemalsuan blanko jual beli hak atas tanah oleh Notaris/PPAT N. Nurhayati S.H.,M.Kn. yang dimana proses penyidikan kasusnya menjadi terhambat karena MKN tidak mengeluarkan surat persetujuan yang berujung pada dihentikannya proses penyidikan atau SP3. Akibat dihentikannya proses penyidikan oleh karena tidak adanya cukup bukti yang disebabkan salah satunya oleh tidak keluarnya izin dari MKN untuk memeriksa Notaris, maka pemohon merasa bahwa haknya untuk memperoleh kesamaan dimuka hukum dan kepastian hukum telah dirugiknan dengan adanya aturan tersebut. Sehingga dalam hal ini, pemohon menyatakan bahwa Putusan MK No. 49/PUU-X/2012 yang menghapus frasa "dengan persetujuan MPD" adalah sangat tepat karena Notaris juga sebagai warga negara maka harus diberlakukan sama dimuka hukum. Berlakunya kembali frasa "dengan persetujuan" dapat menimbulkan adanya ketidakpastian hukum. Berdasarkan alasan tersebut, dalam salah satu petitumnya pemohon memohon untuk membatalkan Pasal 66 ayat (1) UUJNP karena dianggap bertentangan dengan UUD 1945.

\subsubsection{Implikasi Hukum Inkonsistensi Putusan MK terkait Uji Materiil Pasal 66 ayat (1) UUJN}

Permohonan pengujian materiil sejak diundangkannya Pasal 66 ayat (1) UUJN telah 2 (dua) kali dilakukan dengan dasar permohonan yang sama yakni melanggar hak konstitusional warga untuk memperoleh kesamaan dimuka hukum serta untuk mendapatkan kepastian hukum. Pada 2 (dua) gugatan perkara ke MK RI terhadap pasal tersebut, memiliki amar putusan yang berbeda. Bila ditinjau dari bunyi pasal tersebut dimana yang menjadi pokok gugatan adalah adanya frasa "dengan persetujuan MPD" untuk gugatan permohonan pada Putusan MK No.

${ }^{23}$ Bisariyadi, B. (2017). Menyibak Hak Konstitusional yang Tersembunyi. Jurnal Hukum IUS QUIA IUSTUM, 24(4), 509-534, h. 514

${ }^{24}$ Diatmika, I. G. A. O., Atmadja, I. D. G., \& Utari, N. K. S. (2014). Perlindungan Hukum Terhadap Jabatan Notaris Berkaitan Dengan Adanya Dugaan Malpraktek Dalam Proses Pembuatan Akta Otentik. Acta Comitas, 150-160, h.155 
49/PUU-X/2012, sedangkan frasa "dengan persetujuan MKN" pada Putusan MK No. 22/PUUXVII/2019 pada pasal yang sama yakni Pasal 66 ayat (1) UUJNP menunjukan adanya inkonsistensi terhadap putusan yang dikeluarkan oleh MK RI yang terdahulu dengan yang terbaru.

Pada Putusan MK No. 49/PUU-X/2012 amar putusan dari Hakim MK RI adalah mengabulkan seluruhnya permohonan dari pemohon untuk menyatakan bahwa Pasal 66 ayat (1) UUJN bertentangan dengan UUD 1945 dan tidak mempunyai kekuatan hukum mengikat. Majelis hakim berpendapat bahwa ketentuan yang mengatur bahwa proses peradilan yang melibatkan Notaris harus terlebih dahulu mendapatlan persetujuan dari MPD adalah kelompok pesngaturan yang bertentangan dengan prinsip equal protection yang dijamin oleh UUD 1945 terkait persamaan dimuka hukum. Selain itu Majelis hakim juga berpendapat bahwa suatu proses penegakan hukum pidana tidak boleh mendapatkan intervensi dari pihak diluar peradilan, baik itu proses penegakan hukum yang melibatkan Notaris sebagaimana diatur dalam "Pasal 24 UUD 1945 serta dalam Undang-Undang Nomor 48 Tahun 2009 tentang Kekuasaan Kehakiman". Terhadap Notaris diperbolehkan memberikan perlakuan khusus sepanjang sepanjang menyangkut penerapan kode etik, sedangkan Notaris selaku warga negara harus tetap dipandang sama dimuka hukum sehingga diberlakukan pula ketentuan yang sama dengan warga negara lainnya di Indonesia. Keharusan untuk memperoleh persetujuan dari MPD dianggap bertentangan dengan prinsip independensi dan dapat mengakibatkan proses peradilan menjadi berlarut-larut. Berlarut-larutnya proses peradilan maka penegakan terhadap keadilan pun akan menjadi berlarut-larut pula. Untuk itu guna menjaga wibawa seorang Notaris, maka Notaris dalam bertugas dituntut agar selalu bertindak berhati-hati dan profesional. Sehingga berdasarkan pertimbangan-pertimbangan itulah Majelis Hakim MK RI sampai pada amar putusannya tersebut.

Sedangkan pada putusan MK No. 22/PUU-XVII/2019 amar putusan dari Hakim MK RI adalah menolak seluruhnya permohonan dari pemohon. Adapun yang menjadi pertimbangan hakim terahadap dalil yang disampaikan oleh pemohon mengenai materi pada Pasal 66 ayat (1) UUJNP yang berpotensi menghalangi proses penyidikan dalam memperoleh bukti untuk menegakan suatu dugaan tindak pidana karena harus terlebih dahulu memperoleh persetujuan dari MKN dianggap oleh hakim bahwa pemohon tidak memahami secara utuh mengenai norma yang terkandung dalam Pasal 66 ayat (1) UUJNP tersebut. Majelis hakim berpendapat bahwa dengan berlakunya Pasal 66 ayat (1) UUJNP tidak serta merta menghambat proses penyidikan karena MKN sebagaimana lembaga yang ditunjuk untuk berwenang dalam memberikan persetujuan atas pemeriksaan Notaris ataupun pengambilan produk Notaris telah memiliki ketentuan yang mengaturnya. MKN diwajibkan dalam waktu maksimal 30 (tiga puluh hari) sejak permohonan diajukan harus memberikan jawaban atas permohonan tersebuut, bila dalam waktu tersebut tidak ada jawaban maka MKN dianggap memberikan persetujuan, sehingga dalam hal ini Majelis Hakim MK RI tidak sependapat bahwa MKN menjadi penghalang dalam proses penegakan hukum khususnya penyidikan. selain itu ketentuan dalam pasal tersebut juga sebagai perlindungan hukum bagi Notaris dalam menjalankan tugas jabatannya khususnya menjaga keberadaan minuta akta sebagai dokumen negara yang bersifat rahasia.

Ditinjau dari kedua putusan MK RI yang memiliki amar putusan berbeda terhadap pengujian materiil atas Pasal 66 ayat (1) UUJN dan Pasal 66 ayat (1) UUJNP menunjukan adanya inkonsistensi atas putusan tersebut. Meskipun antara Pasal 66 ayat (1) UUJN dan Pasal 66 ayat (1) UUJNP memiliki perbedaan pada badan yang berwenang untuk memberikan persetujuan, namun terkait makna dari ketentuan Pasal tersebut memiliki makna yang sama yakni bahwa untuk melakukan proses peradilan terhadap Notaris para aparat penegak hukum harus mendapatkan persetujuan terlebih dahulu dari sebuah badan yang dapat dikatakan sebagai badan internal dalam Jabatan Notaris. Yang menjadi pokok dari dalil yang diajukan oleh kedua pemohon pada Putusan MK RI tersebut tidak hanya terletak pada badan mana yang memiliki kewenangan untuk memberikan persetujuan, tetapi frasa "dengan sepersetujuan" yang 
sebenarnya membuat pemohon merasa hak konstitusionalnya dilanggar. Terjadinya perbedaan amar putusan berdasarkan pendapat dan pertimbangan Majelis Hakim terhadap suatu pokok perkara dapat dipengaruhi oleh faktor sosiologis, yuridis dan filosofis. Perbedaan persepsi serta alasan hukum yang dimiliki oleh hakim akan mempengaruhi putusan yang dibuatnya. Suatu putusan yang konsisten akan mewujudkan adanya kepastian hukum karena telah terbentuk suatu standar hukum yang digunakan oleh hakim untuk memutus suatu perkara yang sama atau serupa, sehingga para pencari keadilan dapat memprediksikan putusan terhadap perkaranya. Suatu putusan yang konsisten tentunya akan mempermudah pelaksanaan maupun penegakan hukum tersebut. Konsistensi hukum tidak hanya menjamin adanya kepastian hukum, namun berperan penting dalam menjaga kepercayaan masyarakat terhadap peradilan dan penegakan hukum. Sehingga dengan adanya inkonsistensi dalam putusan MK RI, dapat menimbulkan adanya ketidakpastian hukum dalam upaya penegakan hukum terhadap perkara yang berkaitan dengan Notaris serta Produk Notaris. Selain itu, dengan putusan yang tidak konsisten tentunya akan mempengaruhi kepercayaan publik terhadap lembaga peradilan maupun proses peradilan.

\section{Kesimpulan}

Pasca Putusan MK No. 49/PUU-X/2012 tentang permohonan pengujian materiil terhadap Pasal 66 ayat (1) UUJN berdampak pada proses peradilan yang melibatkan Notaris sehingga kewenangan MPD dalam hal itu telah dihapuskan. Aspek perlindungan hukum bagi Notaris dianggap menghilang walaupun Notaris sejatinya tetap memiliki Hak dan Kewajiban Ingkar. Perubahan Pengaturan Notaris pasca Putusan MK RI tersebut kemudian melahirkan UUJNP yang didalamnya kembali memuat aspek perlindungan hukum bagi Notaris dengan ditentukannya MKN sebagai badan yang berwenang dalam memberikan persetujuan kepada Penyidik, Penuntut Umum dan Hakim yang akan melakukan proses peradilan kepada Notaris, yang tertuang dalam "Pasal 66 ayat (1) UUJNP".

Implikasi Hukum atas Inkonsistensi MK No. 49/PUU-X/2012 dan Putusan MK No. 22/PUUXVII/2019 terhadap pengujian materiil Pasal 66 UUJN dan Pasal 66 UUJNP, dapat menimbulkan ketidakpastian hukum serta menurunkan kepercayaan publik terhadap MK RI.

\section{Daftar Pustaka}

Buku

Arliman, L., (2015), Notaris Dan Penegakan Hukum Oleh Hakim, Yogyakarta: CV Budi Utama

Huda, N. \& Nazriyah, R., (2011), Teori dan Pengujian Peraturan Perundang-undangan, Bandung: Nusamedia

Ishaq, (2017), Metode Penelitian Hukum, Bandung: Alfabeta

Marzuki, P.M., (2005), Penelitian Hukum, Jakarta: Prenada Media

Mulyoto, (2010), Kesalahan Notaris Dalam Pembuatan Akta Perubahan Dasar CV, Yogyakarta: Cakrawala Media

Ranggawidjaja, R., (1998), Pengantar Ilmu Perundang-undangan Indonesia, Bandung: Mandar Maju

Ranuhandoko, (2013), Terminologi Hukum, Jakarta: Sinar Grafika

Siahaan, M., (2011), Hukum Acara Mahkamah Konstitusi Republik Indonesia, Edisi 2 Cetakan

1, Jakarta: Sinar Grafika

\section{Jurnal}

Amrizal, J.P. (2011). Implikasi Hukum Putusan Mahkamah Konstitusi, Kanun Jurnal Hukum, 12(53), 77-94

Bisariyadi, B. (2017). Menyibak Hak Konstitusional yang Tersembunyi. Jurnal Hukum IUS QUIA IUSTUM, 24(4), 509-534 
Diatmika, I. G. A. O., Atmadja, I. D. G., \& Utari, N. K. S. (2014). Perlindungan Hukum Terhadap Jabatan Notaris Berkaitan Dengan Adanya Dugaan Malpraktek Dalam Proses Pembuatan Akta Otentik. Acta Comitas, 150-160

Hermawan, U., \& Chalim, M. A. (2017). Kewenangan Majelis Kehormatan Notaris Wilayah Dalam Memberikan Persetujuan Terhadap Pemanggilan Notaris Oleh Penegak Hukum. Jurnal Akta, 4(3), 449-454

Indrayana, D., \& Mochtar, Z. A. (2007). Komparasi Sifat Mengikat Putusan Judicial Review Mahkamah Konstitusi dan Pengadilan Tata Usaha Negara. Mimbar Hukum-Fakultas Hukum Universitas Gadjah Mada, 19(3), 437-454

Kurnianingrum, T. P. (2016). Dampak Hukum Putusan MK No. 49/PUU-X/2012 Terhadap Perlindungan Hukum Bagi Notaris. Kajian, 18(3), 189-201

Munawaroh, N., \& Hidayati, M. N. (2015). Integrasi Pengujian Peraturan Perundang-Undangan di Mahkamah Konstitusi sebagai Upaya Pembangunan Hukum Indonesia. Jurnal Hukum Ius Quia Iustum, 22(2), 255-268

Nafiatul, M., \& Maryam, N.H. (2015). Munawaroh, N., \& Hidayati, M. N. (2015). Integrasi Pengujian Peraturan Perundang-Undangan di Mahkamah Konstitusi sebagai Upaya Pembangunan Hukum Indonesia. Jurnal Hukum Ius Quia Iustum, 22(2), 255-268

Padang, L. A. S. S., (2018), Politik Hukum Kenotariatan Pasca Perubahan Undang-Undang Jabatan Notaris Dalam Menjalankan Jabatannya, Dialogia Iuridica: Jurnal Hukum Bisnis dan Investasi, 9(2),111-126

Soeroso, F. L. (2014). Aspek keadilan dalam sifat final putusan Mahkamah Konstitusi. Jurnal Konstitusi, 11(1), 64-84

Soeroso, F. L. (2014). Aspek keadilan dalam sifat final putusan Mahkamah Konstitusi. Jurnal Konstitusi, 11(1), 64-84

Syafran Sofian, (2014), PP INI Lakukan Sosialisasi Menyeluruh-Empat Pasal Krusial UUJN Perubahan Harus Dipahami, Majalah Renvoi 